\title{
Luminescence dating of the loess/palaeosol sequence at the gravel quarry Gaul/Weilbach, Southern Hesse [Germany]
}

\author{
Esther Dorothe Schmidt, Arno Semmel, Manfred Frechen
}

Abstract:

\begin{abstract}
A thick Middle and Late Pleistocene loess/palaeosol sequence is exposed at the gravel quarry Gaul located east of Weilbach in the southern foreland of the Taunus Mountains. The loess/palaeosol sequence correlates to the last three glacial cycles. Seven samples were dated by luminescence methods using an elevated temperature IRSL (post-IR IRSL) protocol for polymineral fine-grains to determine the deposition age of the sediment and to set up a more reliable chronological framework for these deposits. The fading corrected $\mathrm{IR}_{50}$ and the $\mathrm{pIRIR}_{225}$ age estimates show a good agreement for almost all samples. The fading corrected IRSL ages range from $23.7 \pm 1.6 \mathrm{ka}$ to $>350 \mathrm{ka}$ indicating that the oldest loess was deposited during marine isotope stage (MIS) 10 or earlier and that the humic-rich horizon (Weilbacher Humuszone) was developed during the late phase of MIS 7. Loess taken above the fCc horizon most likely accumulated during MIS 6 indicating that the remains of the palaeosol are not belonging to the last interglacial soil. The two uppermost samples indicate that the youngest loess accumulated during MIS 2 (Upper Würmian). Age estimates for the loess-palaeosol sequence of the gravel quarry Gaul/Weilbach could be obtained up to 350 ka using the pIRIR $_{225}$ from feldspar.
\end{abstract}

[Lumineszenz-Datierung der Löss-Paläoboden-Sequenz in der Kiesgrube Gaul/Weilbach, Südhessen]

Kurzfassung:

Eine mächtige Löss-Paläoboden-Sequenz des Mittel- und Spätpleistozäns ist in der Kiesgrube Gaul östlich von Weilbach im südlichen Taunusvorland aufgeschlossen. Lösse der letzten drei Glazialzyklen, mit zwischengeschalteten Paläoböden, sind aufgeschlossen. Sieben Proben wurden mit der Lumineszenz-Datierungsmethode, basierend auf einem post-IR IRSL Messprotokoll, untersucht, um einen verlässlicheren chronologischen Rahmen für diese Sedimente zu etablieren. Die „fading“ korrigierten IR50 und die pI$\mathrm{RIR}_{225}$ Alter sind für fast alle Proben in guter Übereinstimmung. Die IRSL Alter reichen von $23.7 \pm 1.6 \mathrm{ka}$ bis $>350$ ka und deuten an, dass der älteste Löss während des marinen Isotopenstadiums (MIS) 10 oder früher abgelagert wurde, und dass die Weilbacher Humuszonen sehr wahrscheinlich während einer späten Phase des MIS 7 gebildet wurden. Lösse über dem fCc Horizont wurden sehr wahrscheinlich während des MIS 6 abgelagert, was darauf hindeutet, dass die Reste des Paläobodens nicht mit dem letzten Interglazial korrelieren. Die beiden obersten Proben deuten darauf hin, dass der jüngste Löss während dem letzten Pleniglazial (Oberwürm, MIS 2) abgelagert wurde. Mit dem pIRIR 225 Signal konnten Alter bis $~ 350$ ka für die Proben der Löss-PaläobodenSequenz in der Kiesgrube Gaul gemessen werden.

Keywords: $\quad$ loess, luminescence dating, IRSL, fading, Weilbach, chronostratigraphy

Addresses of authors: M. Frechen, E.D. Schmidt ${ }^{*}$, A. Semmel ${ }^{\dagger}$, Leibniz Institute for Applied Geophysics (LIAG), Section 3: Geochronology and Isotope Hydrology, Stilleweg 2, 30655 Hannover, Germany. E-Mail: Esther.Schmidt@liag-hannover.de, Estherdorothe.Schmidt@googlemail.com; *corresponding author

${ }^{\dagger}$ Einen Tag nach Erhalt eines Briefes mit Korrekturen an unserem gemeinsamen Manuskript, erreichte uns völlig überraschend die traurige Nachricht vom Tode Arno Semmels. Wir werden ihn als Mensch, Kollegen und Wissenschafter vermissen.

\section{Introduction}

Loess records are sensitive archives of climate change and provide important information on local and regional environmental processes and conditions for the Middle and Late Pleistocene period in Europe. The southern foreland of the Taunus mountains (Fig.1), which are part of the Rhenish Massif in Germany, consists mainly of Pleistocene terraces of the river Main covered by thick loess/palaeosol sequences.

For these deposits it was suggested that each palaeosol or fossil Bt horizon (= fossil argillic B horizon) correlates to an interglacial sensu stricto (FinK, 1973). Semmel (1967, 2005) questioned this suggestion because there are loess sequences in Western Europe which contain much more fossil Bt horizons than evidenced by palynological studies. The Upper Pleistocene Lower terraces of the river Main ( $t 6$ and t7 sensu Semmel, 1969) are not covered by such argillic horizons. The stratigraphically older terraces $t 5$ and $t 4$ are covered by loess and intercalated by a fossil Bt horizon and by two Bt horizons, respectively.

In contrast to the studies of SEMmeL (1969), only one burried Bt horizon, intercalating the loess covering terrace $t 4$, was found at the gravel quarry Gaul located east of Weilbach during the excavation of the past years (SEmmel, 2005). The latter Bt horizon is covered by two humic horizons ("Humuszonen"). A significant hiatus truncates the uppermost humic horizon followed by the typical Late Würmian loess succession including Lohne Soil, tundra gleys ("Naßböden") E2 and E3, and the Eltville Tephra (SEMmEL, 1967; stratigraphy after SCHÖNHALS et al., 1964; local description after SEMMEL, 2005a). This loess/palaeosol sequence was studied along an about $1 \mathrm{~km}$ long exposed wall at the gravel quarry Gaul. However, below a weak palaeosol designated to correlate to the Middle Würmian Lohne Soil, a continuous fCc horizon including large, mainly vertical exposed carbonate concre- 


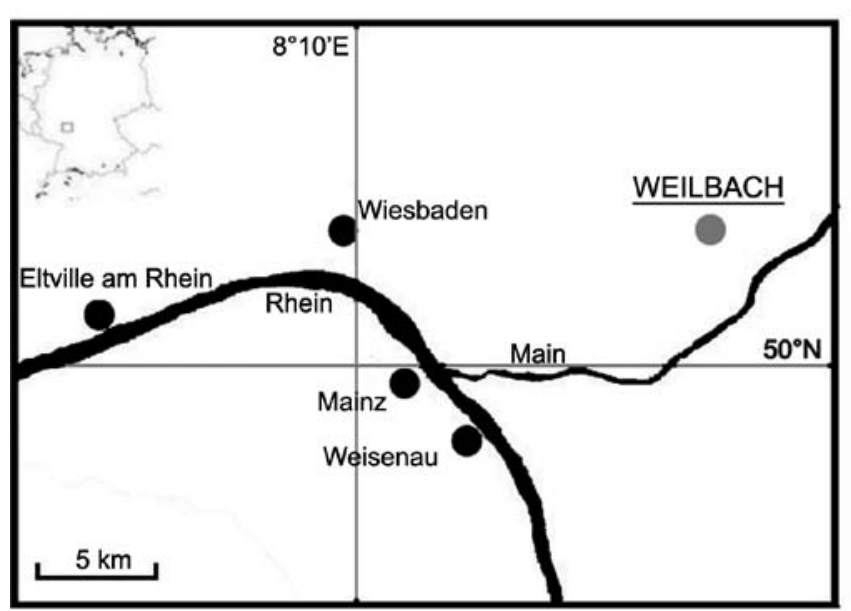

Fig. 1: Map showing the location of the loess/palaeosol sequence exposed at the gravel quarry Gaul/Weilbach.

Abb. 1: Lage der Löss-Paläoboden Sequenz in der Kiesgrube Gaul/Weilbach

tions ("loess dolls") of about $20 \mathrm{~cm}$ length, sometimes with remains of brown clayey loam, was exposed. It is likely that these remains belong to a fossil Bt horizon (SemmeL, 2005). Independent stratigraphical age control is provided by the occurrence of the Eltville Tephra, a widespread marker horizon in this region which most likely resulted from an eruption of the Eifel volcanic field (SEmmel, 2007). The Eltville Tephra has been investigated by several dating studies at different sections. The mean luminescence age values are between $19.2 \mathrm{ka}$ and $20.6 \mathrm{ka}$ for this tephra horizon (WINTLE \& Brunnacker, 1982; ZÖLler, 1989; Frechen \& Preusser, 1996; Antoine et al., 2009). Zöller \& Semmel (2001) provided mean TL age estimates of 21 ka for loess above the Eltville Tephra and 25 ka below. So far numerical age estimates are still lacking for the loess deposits from the Weilbach section making it difficult to interpret the terrestrial climate archives as well as to correlate the loess/palaeosol sequences with other loess records. The nearby loess record from Mainz-Weisenau was described in detail by SEMmeL (1995). Thermoluminescence (TL) age estimates for the deposits of the Mainz-Weisenau section were presented by Buschbeck (1993) and Zöller (1995). Frechen \& PreussER (1996) provided thermoluminescence (TL) and infrared stimulated luminescence (IRSL) age estimates. These previous studies provided TL and IRSL ages up to about $100 \mathrm{ka}$, which was thought to be the upper dating limit that time (FreChen, 1999).

This study presents the first optically stimulated luminescence (OSL) dating results from the loess/palaeosol sequence at the gravel quarry Gaul located east of Weilbach based on a post-IR IRSL measurement sequence. The IRSL signal measured at $50^{\circ} \mathrm{C}$ and the subsequent post-IR IRSL signal measured at $225^{\circ} \mathrm{C}$ using the latter sequence are hereafter referred to as $\mathrm{IR}_{50}$ and $\mathrm{PIRIR}_{225}$, respectively. Our study aims to set up a more reliable chronological framework for this loess/palaeosol sequence. Furthermore, we want to answer the question whether the oldest Bt horizon correlates to the Middle Pleistocene (antepenultimate or penultimate interglacial) or to the Upper Pleistocene.
Loess/palaeosol sequence at the gravel quarry Gaul/ Weilbach

The loess/palaeosol sequence with indicated sample positions for luminescence dating is shown in Fig. 2. The coordinates of the section under study are $55^{\circ} 46^{\prime} 28,7^{\prime \prime} \mathrm{N}$ and $8^{\circ} 44^{\prime} 35,5^{\prime \prime}$ E. The location of the profile under study within the terrace sequence of river Main is shown in Fig. 3. The gravel of terrace $t 4$ is covered by carbonate-free flood loam, which changes to the top into calcareous loess (1 in Fig. 2). Sample Wei 7 was taken from this loess unit. This layer is covered by a $30 \mathrm{~cm}$ thick fCc horizon including large carbonate concretions, which form the bottom of a reddish brown fBt horizon (2 in Fig. 2). The truncated palaeosol is pale coloured owing to secondary carbonate infiltration. In the profile under study the fBt horizon is about $90 \mathrm{~cm}$ thick but varies strongly in thickness along the quarry wall owing to erosion postdating the soil forming processes. The truncated palaeosol is covered by carbonate-rich, greyish brown loess loam (about $30 \mathrm{~cm}$ thick) below a brown spotted dark humic-rich horizon ("Weilbacher Humuszone") (4 in Fig. 2, about $70 \mathrm{~cm}$ thick). Sample Wei6 was taken from this horizon. The humic-rich horizon is covered by a solifluction layer of reworked humicrich material including loess loam and calcareous loess, which is about $60 \mathrm{~cm}$ thick. Sample Wei5 was taken from this unit (5 in Fig. 2). This layer is covered by light brown about $50 \mathrm{~cm}$ thick loess with carbonate pseudomicelium including a truncated fCc horizon with up to $20 \mathrm{~cm}$ large carbonate concretions (6 in Fig. 2). Sample Wei4 was taken from this reworked loess. Along the quarry wall, reddish brown remains of loam are found around these carbonate concretions (Fig. 2a). Close to the profile from Fig.2 a truncated Bt horizon about $60 \mathrm{~cm}$ thick is exposed along the quarry wall above the fCc horizon in a dell filled with loess (Fig. 2b). The uppermost part of the loess/palaeosol sequence includes weak palaeosols correlating to the Middle Würmian Lohne Soil (7 in Fig. 2) and to the Upper Würmian sequence including tundra gley E2 (8 in Fig. 2), tundra gley E3 and the Eltville Tephra (9 in Fig. 2). Sample Wei3 was taken below the Lohne Soil, sample Wei2 below the tundra gley E2 and sample Wei1 below the tundra gley E3.

The stratigraphic interpretation of the profile is based on the local stratigraphical loess scheme (SEMMEL, 1968; 2005) suggesting that the oldest exposed fBt horizon (2 in Fig. 2) correlates to the antepenultimate or penultimate interglacial designated to be older than $\sim 200 \mathrm{ka}$. The humic-rich horizon correlates most likely to the "Weilbacher Humuszone", which correlates to an interstadial period during the early penultimate glacial period (SEMMEL, 1968) and the fCc horizon (6 in Fig. 2) most likely correlates to the last interglacial. The loess sequence covering the fCc horizon correlates most likely to the Middle and Upper Würmian, as indicated by the exposed typical marker horizons.

\section{Experimental details}

The samples were taken in light-tight plastic cylinders and the sediment was extracted under subdued red light and pretreated with $10 \%$ hydrochloric acid to remove carbonates, sodium oxalate to dissolve aggregates and $30 \%$ hydrogen peroxide to remove organic matter. The material was then re- 


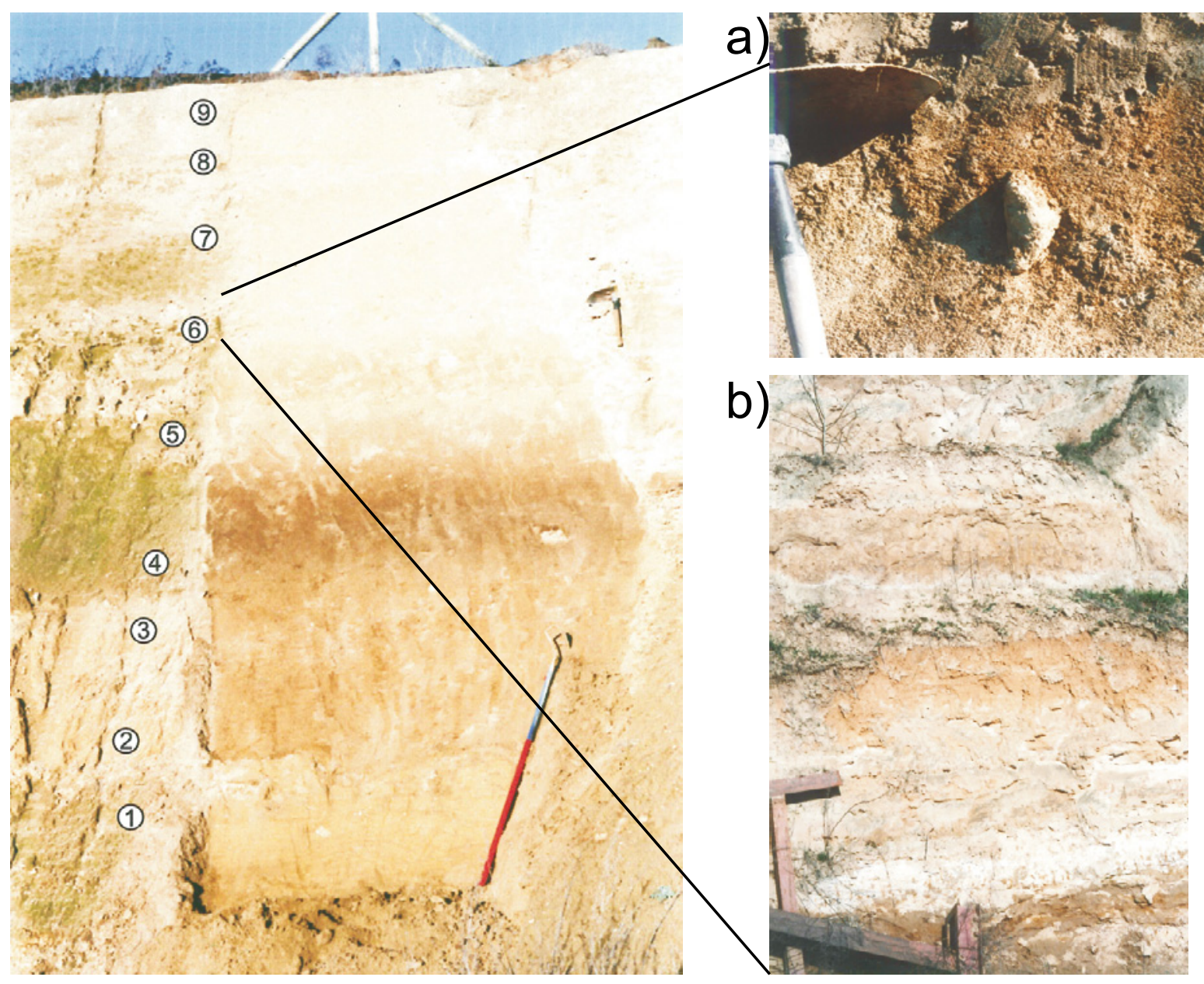

Fig. 2: Loess/palaeosol sequence at the gravel quarry Gaul/Weilbach with a) loess concretions of the fCc horizon with remains of brown Bt material and b) two fossil Bt-horizons near the profile of Fig. 2. $9=$ E3 tundra gley, above the Eltville tephra (Wei1 was taken below), $8=$ E2 tundra gley, greyish compact loess (Wei2 was taken below), 7 = Lohne soil (Wei3 was taken below), $6=$ fCc-horizon with carbonate concretions (Wei4 was taken below), 5 = reworked humic-rich material (Wei5), 4 = humic-rich horizon ("Weilbacher Humuszone") (Wei6), 3 = reworked carbonate-rich loess loam, 2 = fBthorizon, 1 = oldest loess (Wei7)

Abb. 2: Löss-Paläoboden Sequenz in der Kiesgrube Gaul/Weilbach mit a) Lösskindl im fCc-Horizont mit Resten braunen Bt-Lehms und b) zwei fossilen Bt-Horizonten nahe des Hauptprofils. 9 = E3-Nassboden mit hangendem dunkleren Bändchen des Eltviller Tuffs (darunter wurde Wei1 entnommen), 8 = E2-Nassboden, grauer dichter Löss (darunter wurde Wei2 entnommen), 7 = Lohner Boden (olivgrauer feinblattiger Löss mit CaCO ${ }_{3}^{-}$ Pseudomycel) (darunter wurde Wei3 entnommen), 6 = fCc-Horizont mit Lößkindeln (darunter wurde Wei4 entnommen), $5=$ umgelagerte Humuszone (Wei5), 4 = Weilbacher Humuszone (Wei6), 3 = umgelagerter kalkhaltiger Lößlehm, 2 = fBt-Horizont, 1 = ältester Löss (Wei7)

fined to a fine silt $(4-11 \mu \mathrm{m})$ fraction. Finally, samples were prepared for measurement by settling the polymine-ral grains $(4-11 \mu \mathrm{m})$ from acetone onto aluminium discs. All OSL/IRSL measurements were performed using an automated Risø TL/ OSL-DA20 equipped with a ${ }^{90} \mathrm{Sr} /{ }^{90} \mathrm{Y}$ beta source. Feldspar IRSL signals were detected through Schott BG-39 and Corning 7-59 filters (passing 320 to $460 \mathrm{~nm}$; i.e. blue).

Radionuclide concentrations for all samples were obtained using high resolution gamma spectrometry of sediment collected from the immediate surrounding of the samples. A water content of $20 \pm 5 \%$ was estimated for all samples. It has to be mentioned that the estimation of water content since the loess was deposited is associated with a high degree of uncertainty. Mean a-values of $0.08 \pm 0.02$ for polymineral IRSL were used to derive the effective alpha dose rate (REEs-Jones, 1995). The concentrations of uranium, thorium and potassium were converted into infinite-matrix dose rates using the conversion factors of ADAmiEc \& Aitken (1998) and water-content attenuation factors (AITKEN, 1985). Estimation of the cosmic-ray dose rate was calculated according to Prescott \& StePhan (1982) and Prescott $\mho$ Hutton (1994) from knowledge of burial depth, altitude, matrix density, latitude and longitude for each sample. The uranium, thorium, potassium content and total dose rates are shown in Table 1.

\section{Luminescence dating}

Luminescence dating enables to determine the depositional age of various sediments such as loess over a range from a few decades to several hundred thousand years by dating the time that has passed since the last exposure of the minerals0 to daylight (AITKEN, 1998). Quartz or feldspar grains (the most common minerals in sediments) are used as natural dosimeters. They are able to store energy within their crystal structure, which is coming mainly from an omnipresent ionising radiation (alpha, beta and gamma) as well as from cosmic radiation. The charge can be stored in imperfections in the crystal lattice for long periods. In the laboratory the grains are first heated, and then stimulated with IR or blue LEDs which release the electrons from their traps in the form of 


\section{NW}

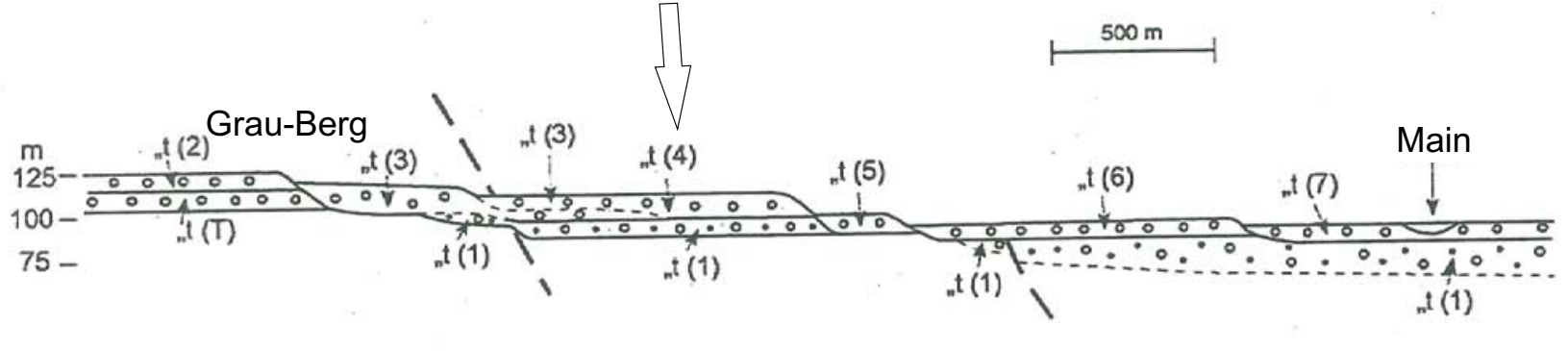

Fig. 3: Terrace sequence of the river Main in the southern foreland of the Taunus mountains. The Loess/palaeosol sequence is located close to the symbol "t4". Abb. 3: Schnitt durch die Main-Terrassenfolge im südlichen Taunusvorland. Das beprobte Profil liegt nahe dem Symbol „t4“.

visible light (luminescence). Such a measurement allows estimating the dose of radiation (palaeodose or equivalent dose, De) which the crystal has absorbed since the last exposure to daylight. The luminescence signals from feldspars grow to much higher doses than those from quartz, which offers the possibility of significantly extending back the age range. However, luminescence dating of feldspars has a tendency to underestimate the geological age, because of anomalous fading (WintLE, 1973) which is caused by quantum-mechanical tunnelling (Visocekas, 1985). Feldspar dating is normally carried out using a $50^{\circ} \mathrm{C}$ IR stimulation with detection in the blue (-violet) spectrum. IRSL ages underestimate often consistently the quartz OSL ages most likely due to anomalous fading. Several methods of age corrections have been proposed (e.g. HuntLEy \& LAMOTHE, 2001; LAMOTHE et al., 2003) and many studies show corrected IRSL ages which are in good agreement with quartz OSL ages. But these corrections rely on different assumptions, including e.g. the fact that the logarithmic time dependence is relevant to geological time (HuNTLEY \& LAмотнE, 2001) and there is no general consensus which correction method should be used. Furthermore, the correction method is strictly applicable only for natural doses in the linear region of the growth curve (HunTLEY \& LAMOTHE, 2001), although BuYLAERT et al. (2009; in press) have shown that the correction can give accurate ages outside this range. However, if the fading rate can be reduced, feldspar dating will be more reliable.

\section{Post-IR IRSL measurement sequence}

Thomsen et al. (2008) found out, that stimulation at elevated temperatures significantly reduces the fading rate. Based on this work Buylaert et al. (2009) proposed a new single aliquot regenerative dose (SAR) protocol, with detection in the blue (320-460 nm). This protocol which includes elevated temperature stimulation with IR for $100 \mathrm{~s}$ at $225^{\circ} \mathrm{C}$, following stimulation with IR for $100 \mathrm{~s}$ at $50^{\circ} \mathrm{C}$, is called post-IR IRSL measurement sequence and is presented in Table 2. Buylaert et al. (2009) have shown that the observed fading rates for the post-IR IRSL signal are significantly lower than from the conventional $\mathrm{IR}_{50}$ and that the signal is bleachable in nature. Buylaert et al. (submitted) measured a mean residual dose value of $10 \pm 2$ Gy on polymineral fine-grains extracted from modern Chinese loess. This post-IR IRSL measurement protocol is applied to the polymineral fine-grains from the Weilbach section. The initial $2.0 \mathrm{~s}$ of the post-IR IR signal is used for calculating the De values, with a background subtraction based on the signal observed in the last $10 \mathrm{~s}$ of the decay curve. All dose response curves were fitted using an exponential saturating function. Tests were carried out on the same aliquots as for De measurement to check for anomalous fading and to compare the fading rates of the $\mathrm{IR}_{50}$ and the $\operatorname{pIRIR}_{225}$. The aliquots were dosed, preheated and then stored for various delays after irradiation and before measurement. This sequence was repeated several times on each aliquot. The fading rates are expressed in terms of the percentage of the decrease of intensity per decade of time ( $\mathrm{g}$ value; Aitken, 1985; Auclair, Lamothe \& Huot, 2003). The g-values were calculated according to HuNTLEY \& LAMOTHE (2001) using the same integration limits as for the De calculation. The g-values were used to correct the ages.

Tab. 1: Dose rate data from potassium, uranium and thorium content, as measured by gamma spectrometry.

Tab. 1: Dosimetrische Ergebnisse basierend auf Kalium, Uran und Thorium Gehalt (gemessen mit Gammaspektrometrie).

\begin{tabular}{|c|c|c|c|c|c|}
\hline Sample & Uranium (ppm) & Thorium (ppm) & Potassium (\%) & $\begin{array}{c}\text { Cosmic dose rate } \\
\text { (Gy/ka) }\end{array}$ & $\begin{array}{c}\text { IRSL dose rate } \\
\text { (Gy/ka) }\end{array}$ \\
\hline Wei 1 & $3.03 \pm 0.03$ & $10.09 \pm 0.06$ & $1.23 \pm 0.01$ & $0.19 \pm 0.02$ & $3.00 \pm 0.16$ \\
Wei 2 & $3.40 \pm 0.03$ & $11.24 \pm 0.06$ & $1.38 \pm 0.01$ & $0.18 \pm 0.02$ & $3.32 \pm 0.18$ \\
Wei 3 & $3.24 \pm 0.02$ & $11.41 \pm 0.06$ & $1.30 \pm 0.01$ & $0.14 \pm 0.01$ & $3.18 \pm 0.17$ \\
Wei 4 & $2.76 \pm 0.02$ & $9.38 \pm 0.05$ & $1.18 \pm 0.01$ & $0.13 \pm 0.01$ & $2.72 \pm 0.15$ \\
Wei 5 & $2.80 \pm 0.03$ & $11.12 \pm 0.06$ & $1.31 \pm 0.01$ & $0.12 \pm 0.01$ & $3.01 \pm 0.16$ \\
Wei 6 & $3.33 \pm 0.03$ & $13.55 \pm 0.06$ & $1.43 \pm 0.01$ & $0.09 \pm 0.01$ & $3.45 \pm 0.18$ \\
Wei 7 & $2.92 \pm 0.03$ & $10.73 \pm 0.06$ & $1.30 \pm 0.01$ & $0.06 \pm 0.01$ & $2.94 \pm 0.16$ \\
\hline
\end{tabular}


a)

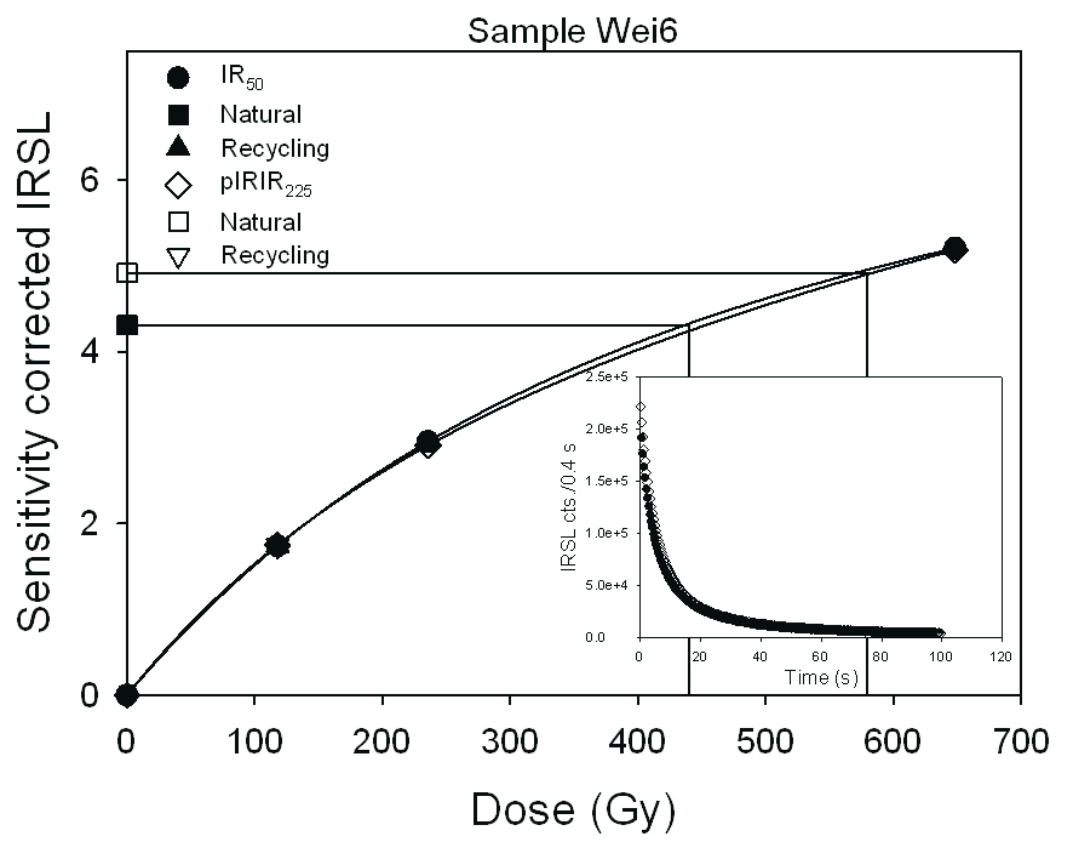

b)



Luminescence characteristics and performance tests

Figure 4 shows the dose response curves and the decay curves for the $\mathrm{IR}_{50}$ and the pIRIR ${ }_{225}$ for the stratigraphically oldest samples Wei6 (Fig. 4a) and Wei7 (Fig. 4b). These curves are selected to be representative for all samples. The natural $\mathrm{IR}_{50}$ has about $10-15 \%$ lower signal intensity than the natural pIRIR $_{225}$. The growth curves for the pIRIR 225 lies above the curve for the $\mathrm{IR}_{50}$ for all samples. However, the shapes of the growth curves are indistinguishable. BuYLAERT et al. (2009) observed that the shape of the growth curves for the $\mathrm{IR}_{50}$ and the pIRIR $_{225}$ are indistinguishable for their samples. The pIRIR $_{225}$ of all the measured samples is much brighter $(\sim 10-$
$15 \%$ ) than for the $\mathrm{IR}_{50}$ (inlay of Fig. $4 \mathrm{a}$ and b) confirming the results of BUYLAERT et al. (2009). Recycling ratios for the samples range from $0.98 \pm 0.03$ to $1.01 \pm 0.003$ for the $\mathrm{IR}_{50}$ and from $0.91 \pm 0.04$ to $0.99 \pm 0.003$ for the pIRIR $_{225}$. Recuperation is below $5 \%$ of the natural signal. To test the applicability of the post-IR IRSL protocol using a stimulation temperature of $225^{\circ} \mathrm{C}$, the dose recovery ratio was measured for all samples (Murray \& Wintle, 2003). The aliquots were bleached for 4 hours in a Hönle SOL2 solar simulator before giving a dose approximately equal to the natural dose, except for sample Wei7, where a smaller dose was chosen. This dose was then measured in the same manner as the equivalent dose in or- 
a)

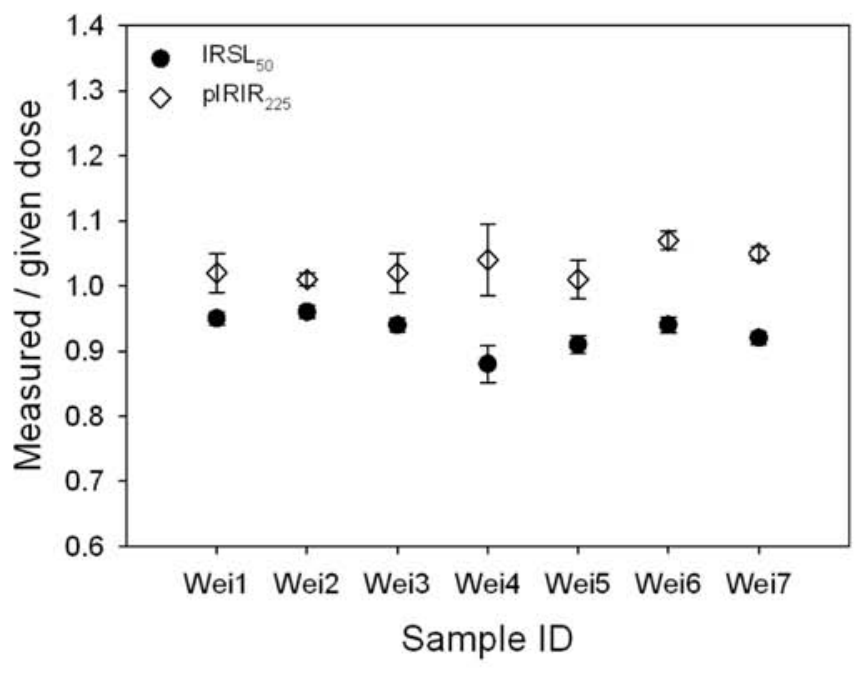

b)

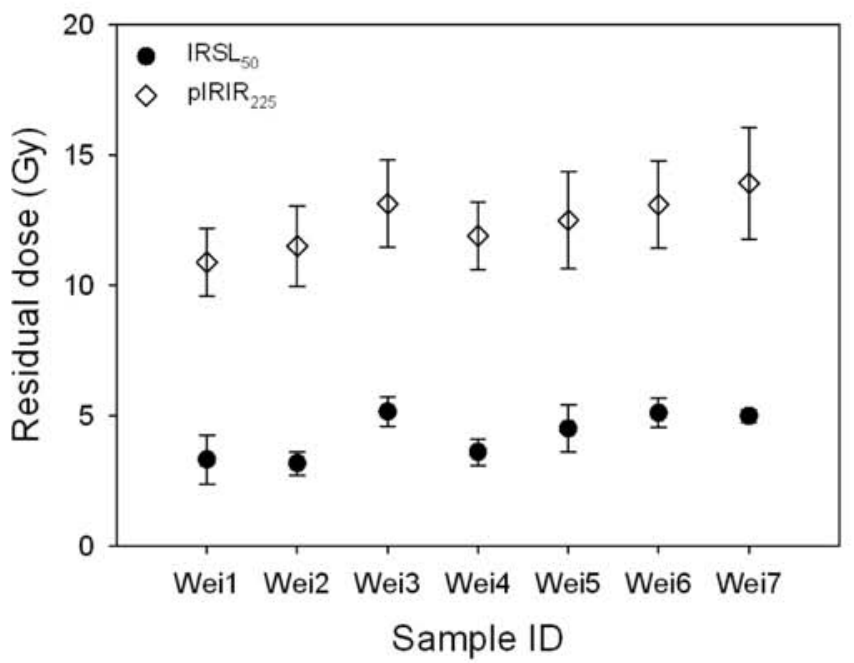

Fig.5: Dose recovery test (a) and the residual doses (b) for the $I R_{50}$ and the $\mathrm{pIRIR}_{225}$ signal for all samples. Three aliquots were measured per sample. Error bars represent 1-sigma standard error.

$A b b$. 5: Dose recovery test (a) und residuale Dosen (b) für das $I R_{50}$ und das pIRIR $_{225}$ Signal für alle Proben. Drei Aliquots wurden pro Probe gemessen. Die Fehlerbalken stellen den 1-sigma Standardfehler dar.

der to confirm that the protocol is able to recover a known dose successfully. If the SAR protocol is suitable, the measured to given dose ratio should be close to 1 . Fig. 5 a shows the results of the dose recovery test for all samples for the $I_{50}$ and the pIRIR 225 . The obtained ratios of the measured to given dose range from $0.88 \pm 0.02$ to $0.94 \pm 0.01$, with a mean of $0.93 \pm 0.01 \mathrm{~Gy}(\mathrm{n}=21)$ for IR50 and from $1.01 \pm 0.03$ to $1.07 \pm 0.01$, with a mean of $1.03 \pm 0.01$ Gy $(n=21)$ for pIR$\mathrm{IR}_{225}$. This data indicates the applicability of the post-IR IRSL protocol. To confirm that the IRSL and the post-IR IRSL are bleachable by natural daylight we exposed three aliquots per sample for four hours to a Hönle SOL2 solar simulator and then measured the apparent dose in the usual manner. The results are shown in Fig. $5 \mathrm{~b}$ and Table 3. The residual doses range from $3.2 \pm 0.5$ Gy to $5.6 \pm 0.2 \mathrm{~Gy}$, with a mean of $4.4 \pm$ $0.9 \mathrm{~Gy}(\mathrm{n}=7)$ for $\mathrm{IR}_{50}$ and from 10.9 $\pm 1.3 \mathrm{~Gy}$ to $14.9 \pm 2.1 \mathrm{~Gy}$, with a mean of $12.7 \pm 0.5 \mathrm{~Gy}(\mathrm{n}=7)$ for $\operatorname{pIRIR}_{225}$.

\section{Equivalent Dose $\left(D_{e}\right)$, fading rates and age estimates}

In Table 3 the equivalent doses, dose recovery results, residual doses, g-values and the resulting luminescence ages, both uncorrected as well as fading corrected, are summarized for all samples. The $\mathrm{D}_{\mathrm{e}}$-s obtained using the $\mathrm{IR}_{50}$ from feldspar range from $52.9 \pm 1.3$ Gy to $423 \pm 4$ Gy. The obtained equivalent doses gave uncorrected age estimates between $17.6 \pm 1.1 \mathrm{ka}$ and $139 \pm 8 \mathrm{ka}$. $\mathrm{D}_{\mathrm{e}}$ values obtained for the $\mathrm{IR}_{50}$ increase clearly with depth from sample Wei1 to sample Wei5. The values obtained for sample Wei6 and Wei7 do not increase considerably with depth indicating that this signal is in field saturation at $\sim 400 \mathrm{~Gy}$. The $\mathrm{D}_{\mathrm{e}}-\mathrm{s}$ calculated using the pIRIR $_{225}$ from feldspar range from $64.9 \pm 2.3$ Gy to $921 \pm$ $41 \mathrm{~Gy}$. The $\mathrm{D}_{\mathrm{e}}$ values are in average $\sim 20 \%$ higher than those obtained using the $\mathrm{IR}_{50}$. The pIRIR 225 does not show evidence of field saturation (equilibrium between the accumulation of new charge and the loss by anomalous fading), and increases with depth. The characteristic saturation doses $\left(\mathrm{D}_{0}\right)$ are about $\sim 450$ Gy for the $\mathrm{IR}_{50}$ and the $\mathrm{PIRIR}_{225}$. According to WintLe \& MURRAY (2006) it is only possible to obtain reliable equivalent doses $\left(\mathrm{D}_{\mathrm{e}}\right)$ up to a dose value of $2 \mathrm{D}_{0}$ and therefore it is important to test if the equivalent dose values exceed $2 \mathrm{D}_{0}$. Following this suggestion it is possible to measure $D_{e}$ values up to about $\sim 900$ Gy for our material. Fading tests were carried out for all samples using the post-IR IRSL measurement sequence. The g-values are shown in Fig. 6 for the $\mathrm{IR}_{50}$ and the $\mathrm{pIRIR}_{225}$. The g-values range from $2.9 \pm 0.3 \% /$ decade to $3.2 \pm 0.2 \% /$ decade, with an average of $3.01 \pm 0.04 \% /$ decade $(n=7)$ for the $\mathrm{IR}_{50}$ and from $1.6 \pm 0.3 \% /$ decade to 2.0 $\pm 0.4 \%$ /decade, with an average of $1.8 \pm 0.1 \% /$ decade $(n=7)$ for the $\mathrm{pIRIR}_{225}$ indicating that the $\mathrm{pIRIR}_{225}$ fades $\sim 40 \%$ less than the $\mathrm{IR}_{50}$. The fading corrected ages are listed in Table 3. Fading corrections use the methods proposed in HuNTLEY \& LAмотне (2001). The fading corrected age estimates for the $\mathrm{IR}_{50}$ range from $23.7 \pm 1.6 \mathrm{ka}$ to $>190 \mathrm{ka}$ and from $25.2 \pm 1.6$ $\mathrm{ka}$ to $>350 \mathrm{ka}$ for the $\mathrm{PIRIR}_{225}$. The $\mathrm{IR}_{50}$ and the $\mathrm{pIRIR}_{225}$ are in agreement for samples Wei1-Wei6. For sample Wei7 the $\mathrm{IR}_{50}$ underestimates the pIRIR 225 . We assume that the fading corrected pIRIR $_{225}$ values yield more reliable age estimates. The $\mathrm{IR}_{50}$ is most likely in field saturation for sample Wei7. The pIRIR $_{225}$ age estimate for sample Wei7 (>350 ka) can be regarded as minimum age only, as the $\mathrm{D}_{\mathrm{e}}$ value of $921 \pm 41 \mathrm{~Gy}$ is in the range of $2 \mathrm{D}_{0}$.

\section{Discussion}

Our study presents the first luminescence age estimates for the loess/palaeosol sequence of the gravel quarry Gaul located east of Weilbach based on an elevated temperature infrared stimulated luminescence (IRSL) signal which has been shown to fade at a very much lower rate than the conventional IRSL signal (Thomsen et al., 2008, Buylaert et al., 2009). The fading corrected $\mathrm{IR}_{50}$ and the pIRIR ${ }_{225}$ show good agreement for samples Wei1-Wei6. For sample Wei7 the $\mathrm{IR}_{50}$ underestimates the $\operatorname{PIRIR}_{225}$. Our interpretation is hence based on the fading corrected pIRIR ${ }_{225}$ age estimates (Fig. 7). Sample Wei7, which was taken from the calcareous loess covering 


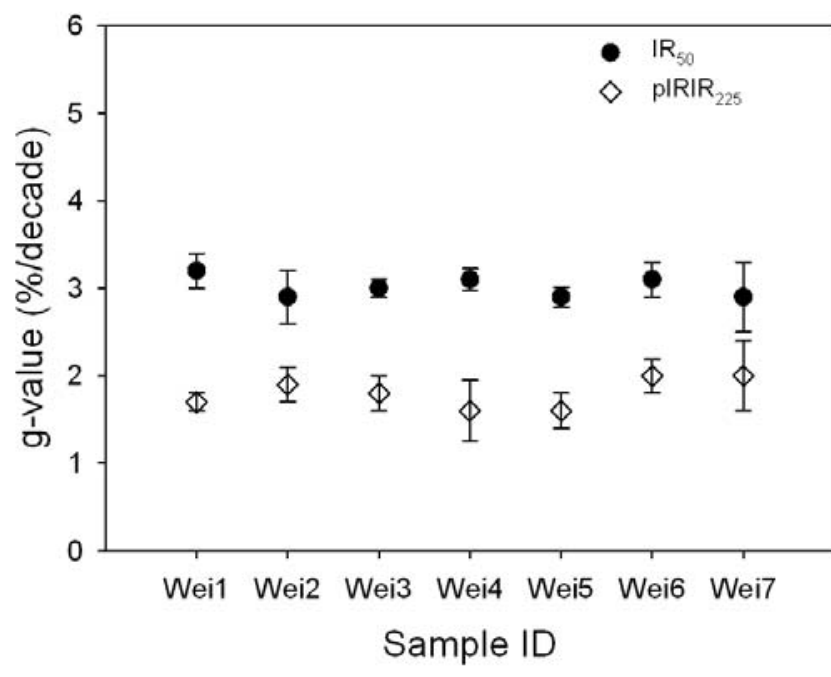

Fig. 6: Fading rates for the post the $I R_{50}$ and $p I R I R_{225}$ signals for all samples. Three aliquots were measured per sample. Error bars represent 1-sigma standard error.

Abb. 6: Fadingraten für das $I R_{50}$ und das IRIR $_{225}$ Signal für alle Proben. Drei Aliquots wurden pro Probe gemessen. Die Fehlerbalken stellen den 1-sigma Standardfehler dar.

the gravel of terrace $t 4$ ( 1 in Fig. 2$)$ yielded an age estimate of $>350$ ka indicating loess deposition during marine Isotope Stage (MIS) 10 or earlier and suggesting that terrace $t 4$ has a minimum deposition age of $\sim 350 \mathrm{ka}$. The calcareous loess is covered by a fCc horizon which forms the bottom of a reddish brown fBt horizon (2 in Fig. 2). This truncated palaeosol is covered by about $30 \mathrm{~cm}$ thick loess loam and a brown dark humic-rich horizon (4 in Fig. 2).

Sample Wei6 was taken from this layer and yields an age estimate of $198 \pm 12 \mathrm{ka}$ indicating a formation of the "Weilbacher Humuszone" during the late phase of MIS 7. Thus the oldest reddish brown fBt horizon (2 in Fig. 2) is older than $\sim 200 \mathrm{ka}$ and was most likely developed during the antepenultimate or penultimate interglacial. The humic-rich horizon is covered by a solifluction layer of reworked humic-rich material including loess loam and calcareous loess (Sample Wei5 was taken from this horizon, 5 in Fig. 2). This layer yielded an age estimate of $202 \pm 14 \mathrm{ka}$ and is covered by about 50 $\mathrm{cm}$ thick reworked loess (Wei4) with macroscopically visible pseudomicelium, which gives an age estimate of $203 \pm 22 \mathrm{ka}$. These layers can probably be correlated with a cold phase during MIS 7. It has to be mentioned that samples Wei5 and Wei4 were taken from reworked material. They could eventually be contaminated with older material, which would lead to an age overestimation. Therefore the ages have to be regarded more carefully. The reworked loess is covered by a fCc horizon with up to $20 \mathrm{~cm}$ large carbonate concretions (6 in Fig. 2). Reddish brown remains of loam are found around these carbonate concretions (Fig. 2a). Above the fCc horizon loess accumulated; sample Wei3 was taken from this horizon and yielded an age estimate of $146 \pm 9$ ka indicating accumulation during the penultimate glaciation (MIS 6). This result shows that the remains of the palaeosol very likely do not correlate to the last interglacial period but very likely correlate to a warm phase of MIS 7. The last interglacial soil (MIS 5) and the deposits of the lower Würmian are missing in this profile. BIBUS, RäHLE \& WEDEL (1996, 2002) provided a detailed description of the latter ones from the Mainz-
Weisenau section and Frechen \& Preusser (1996) provide TL and IRSL age estimates ranging from 68-113 ka for these deposits. The results of BiBus, RÄHLE \& WedEL (1996, 2002) show that there is evidence for three warmer phases after the last interglacial, revealing the significant hiatus for our profile. Above the loess layer the Middle Würmian Lohne Soil (7 in Fig. 2) is developed followed by an Upper Würmian sequence including tundra gley E2 (8 in Fig. 2), tundra gley E3 and the Eltville Tephra (9 in Fig. 2). Sample Wei2 was taken below the tundra gley E2 giving an age estimate of $28.1 \pm 2.3$ ka and Sample Wei1 below the tundra gley E3 yielding an age estimate of $25.2 \pm 1.6 \mathrm{ka}$ indicating accumulation during the last Pleniglacial (Upper Würmian) correlating to MIS2. Frechen \& Preusser (1996) obtained age estimates of $\sim 20 \mathrm{ka}$ for the Eltville tephra and ZöLLER \& SEMMEL (2001) provided mean TL age estimates of $21 \mathrm{ka}$ for loess above the Eltville Tephra and 25 ka below. According to Frechen (1999) an eruption age between 17-23 ka for the Eltville tephra is most likely, which is in good agreement with our results.

Our results are not in complete agreement with the loess stratigraphy proposed by SEMmEL (1968, 2005). However, they support the assumption that the oldest exposed $\mathrm{fBt}$ horizon (2 in Fig. 2) correlates to the antepenultimate or penultimate interglacial and that the humic-rich horizon most likely correlates to the "Weilbacher Humuszone", designated to be an interstadial period during the early penultimate glacial period (SEMMEL, 1968). But contrary to the suggestion that the fCc horizon (6 in Fig. 2) most likely correlates to the last interglacial, an age estimate of $146 \pm 9 \mathrm{ka}$ was obtained for the loess sediments accumulated above the fCc horizon and the carbonate concretions. This age estimate indicates that the soil formation correlates most likely to a warm phase of MIS 7. Sample Wei1 and Wei 2 are in good agreement with the stratigraphical loess scheme (SEMmEL, 1968; 2005) and support the assumption that this loess deposits correlates to the Upper Würmian, which is also indicated by the exposed typical marker horizons.

\section{Conclusion}

In our study we applied an elevated temperature IRSL (postIR IRSL) protocol for polymineral fine-grains of the loess/ palaeosol sequence at the gravel quarry Gaul/Weilbach (i) to set up a more reliable chronological framework for this loess/palaeosol sequence and (ii) to answer the question whether the oldest Bt horizon correlates to the Middle Pleistocene (antepenultimate or penultimate interglacial) or to the Upper Pleistocene (last interglacial). Performance tests such as dose recovery and residual checks were carried out to confirm the suitability of our SAR protocol. The $\mathrm{IR}_{50}$ and the pIRIR $_{225}$ signals are in good agreement for samples Wei1Wei6. For sample Wei7 the $\mathrm{IR}_{50}$ underestimates the pIRIR ${ }_{225}$. Fading corrected $\mathrm{IR}_{50}$ and $\mathrm{pIRIR}_{225}$ ages range from $23.7 \pm 1.6$ to $>350 \mathrm{ka}$. These age estimates indicate that the oldest loess was deposited during marine isotope stage (MIS) 10 or earlier suggesting that the terrasse $t 4$ yield a minimum age of $\sim 350$ ka. According to our results the humic-rich horizon was developed during the late phase of MIS 7 and can hence be correlated to the "Weilbacher Humuszone". The oldest exposed fBt horizon most likely correlates to the antepenultimate or penultimate interglacial. Loess above the fCc horizon most 


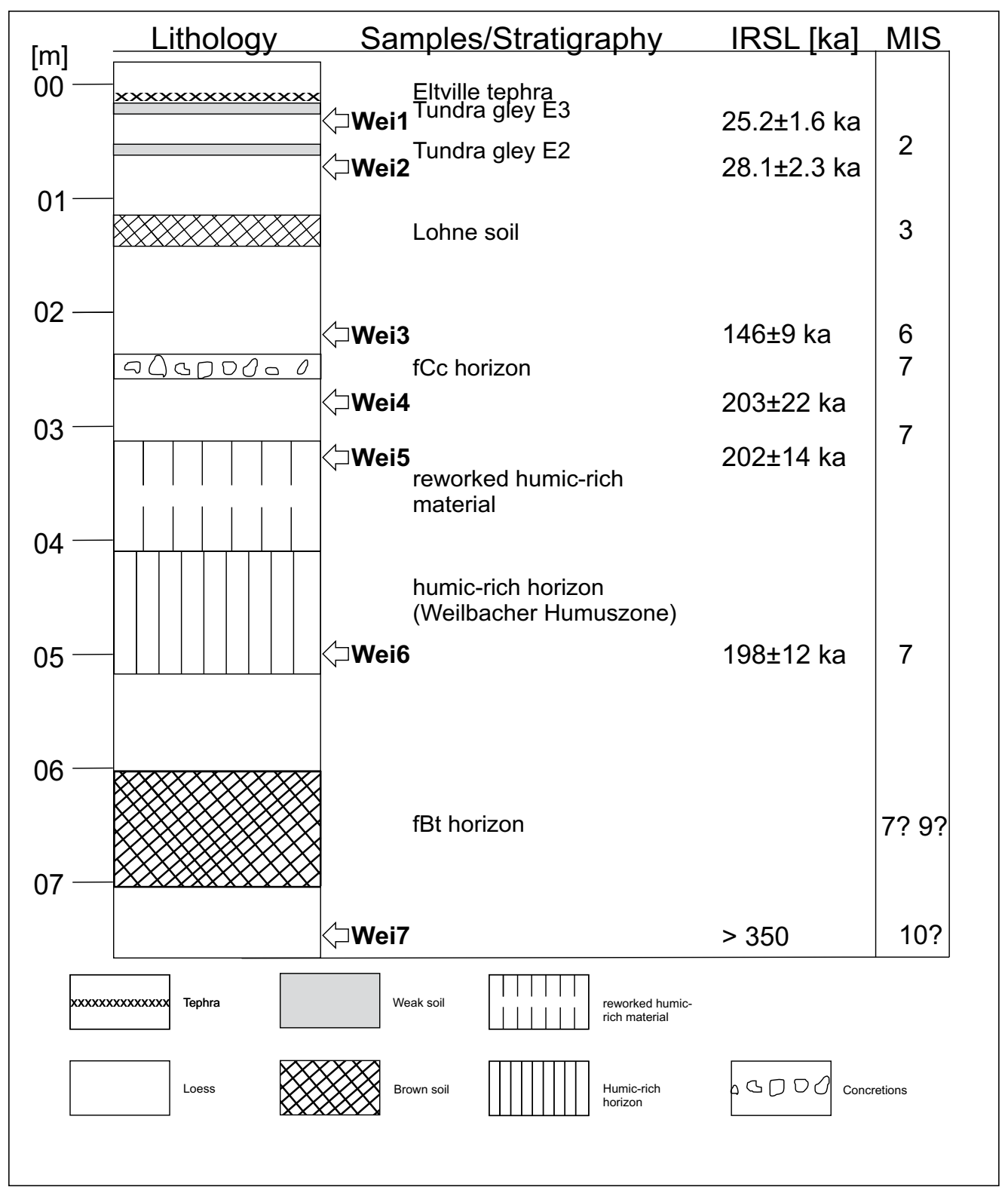

Fig. 7.: Lithology and luminescence ages of the loess/palaeosol sequence exposed at the gravel quarry Gaul/Weilbach. Fading corrected pIRIR 225 age estimates are presented.

Abb. 7: Lithologie und Lumineszenzalter für die Löss-Paläoboden Sequenz in der Kiesgrube Gaul/Weilbach basierend auf den fading korrigierten pIRIR ${ }_{225}$ Altern.

Table 2: The elevated temperature post-IR IRSL measurement.

Tabelle 2: Post-IR IRSL Messprotokoll.

\begin{tabular}{|cll|}
\hline Step & Treatment & Observed \\
\hline 1 & Dose & \\
2 & Preheat, 60 s at $250^{\circ} \mathrm{C}$ & $\mathrm{Lx}$ \\
3 & IR stimulation, $100 \mathrm{~s}$ at $50^{\circ} \mathrm{C}$ & $\mathrm{Lx}$ \\
4 & IR stimulation, $100 \mathrm{~s}$ at $225^{\circ} \mathrm{C}$ & \\
5 & Test dose & $\mathrm{Tx}$ \\
6 & Preheat, 60 s at $250^{\circ} \mathrm{C}$ & $\mathrm{Tx}$ \\
7 & IR stimulation, $100 \mathrm{~s}$ at $50^{\circ} \mathrm{C}$ & \\
8 & IR stimulation, $100 \mathrm{~s}$ at $225^{\circ} \mathrm{C}$ & \\
9 & IR stimulation, 40 s at $290^{\circ} \mathrm{C}$ & \\
10 & Return to step 1 & \\
\hline
\end{tabular}






likely accumulated during MIS 6 indicating that the remains of the palaeosol do not correlate to the last interglacial soil. The two uppermost samples indicate that the youngest loess was accumulated during MIS 2 (Upper Würmian). This is in good agreement with the results of other dating studies regarding the Eltville tephra.

\section{Acknowledgements}

This research is part of a $\mathrm{PhD}$ study in the frame of the "Leibniz Pakt für Forschung und Innovation" at the LIAGInstitute in Hanover. Ludwig Zöller and Lara Wacha are thanked for the useful comments on the manuscript.

\section{References}

AdAmiec, M. \& Aitken, M.J. (1998): Dose-rate conversion factors: update. - Ancient TL 16: 37-50.

Aitken, M.J. (1985): Thermoluminescence Dating, London, 359 pp.

Aitken, M.J. (1998): An Introduction to Optical Dating, Oxford, 267 pp.

Antoine, P., Rousseau, D.-D., Moine, O., Kunesch, S., Hatté, C., Lang, A., Tissoux, H. \& Zöller, L. (2009): Rapid and cyclic eolian deposition during the Last Glacial in European loess: a high-resolution record from Nussloch, Germany. - Ouaternary Science Reviews 28: 2955-2973.

Auclair, M., LAMOTHE, M. \& HUOT, S. (2003): Measurement of anomalous fading for feldspar IRSL using SAR. - Radiation Measurements 37: 487-492.

Bibus, E., RÄHLE \& Wedel, J. (2002): Profilaufbau, Molluskenführung und Parallelisierungs-möglichkeiten des Altwürmabschnitts im Lößprofil Mainz-Weisenau. - Eiszeitalter und Gegenwart 51: 1-14.

Bibus, E., W. Bludau, W., C. Bross, C. \& RÄhle, W. (1996): Der Altwürmund Rissabschnitt im Profil Mainz-Weisenau. Frankfurter geowissenschaftliche Arbeiten D20: 21-52.

Buschbeck, H.M. (1993): Thermolumineszenz und ihre Anwendung zu Altersbestimmungen in Geologie und Archäologie. - Diss. Univ. Frankfurt, p.155.

Buylaert J.-P., Thiel, C., Murray, A.S., Vandenberghe, D.A.G., Yi, S. \& Lu, H., submitted. IRSL and post-IR IRSL residual doses recorded in modern dust samples from the Chinese Loess Plateau. Geochronometria.

Buylaert, J.P., Murray, A.S., Thomson, K.J. \& Jain, M. (2009): Testing the potential of an elevated temperature IRSL signal from K-feldspar. -Radiation Measurements 44: 560-565.

FINK, J. (1973): Internationale Lößforschung, Bericht der INQUA-Lößkommission. - Eiszeitalter \& Gegenwart 23/24: 415-426.

Frechen, M. (1999): Upper Pleistocene loess stratigraphy in Southern Germany. Quaternary Science Reviews 18: 243-269.

Frechen, M. \& Preusser, F. (1996): Kombinierte Lumineszenz-Datierungen am Beispiel des Lößprofils Mainz-Weisenau. - Frankfurter geowissenschaftliche Arbeiten D 20: 53-66.

Huntley, D.J. \& LAMOTHE, M. (2001): Ubiquity of anomalous fading in Kfeldspars and the measurement and correction for it in optical dating. - Canadian Fournal of Earth Sciences 38: 1093-1106.

Lamothe M., Auclair M., Hamzaoui C. \& Huot S. (2003): Towards a prediction of long-term anomalous fading of feldspar IRSL. - Radiation Measurements 37: 493-498.

Murray, A.S. \& Wintle, A.G. (2003): The single regenerative dose protocol: potential for improvements in reliability. - Radiation Measure ments 37: 377-381.

Murray, A.S. \& Olley, J.M. (2002): Precision and accuracy in the optically stimulated luminescence dating of sedimentary quartz: a status review. - Geochronometria 21: 1-16.

Prescott, J.R. \& Hutton, J.T. (1994): Cosmic ray contribution to dose rates for luminescence and ESR dating: large depths and long-term time variations. - Radiation Measurements 23: 497-500.

Prescott, J.R. \& Stephan, L.G. (1982): The contribution of cosmic radiation to the environmental dose for thermoluminescence dating. PACT 6: 17-25.

ReEs-Jones, J. (1995): Optical dating of young sediments using fine-grain quartz. - Ancient TL 13: 9-14.

RoBERTs, H.M. (2008): The development and application of luminescence dating to loess deposits: a perspective on the past, present and future - Boreas 37: 483-507. 
Schönhals, E., Rohdenburg, H. \& Semmel, A. (1964): Ergebnisse neuerer Untersuchungen zur Würmlöß-Gliederung in Hessen. - Eiszeitalter \& Gegenwart 15: 199-206.

Semmel, A. (1967): Neue Fundstellen von vulkanischem Material in hessischen Lössen. - Notizbl. hess. L.-Amt Bodenforschung 94: 104-108.

Semmel, A. (1968): Studien über den Verlauf jungpleistozäner Formung in Hessen. - Frankfurter geogr. Hefte 45: $133 \mathrm{~S}$.

Semmel, A. (1969): Quartär.- Erl. geol. Kte. Hessen, Bl. 5916 Hochheim a.M.: 51-99, Wiesbaden.

Semmel, A. (1995): Quarry of the Portlandzementwerke Heidelberg at Mainz-Weisenau. - In: Schirmer, W. (ed.): Quaternary field trips in Central Europe, 1: 452-454, München.

Semmel, A. (2005): Probleme der Abgrenzung und Datierung pleistozäner Terrassen - erörtert an Beispielen aus dem Untermaingebiet. - Geologisches Jahrbuch Hessen 132: 113-129.

Semmel, A. (2005a): 7. Exkursionshalt IV Paläopedologische Probleme im Löß am Mainzer Dreieck S Hofheim a.Ts. - 51 S., Selbstverlag Hofheim/Ts.

Semmel, A. (2007): Löss als Indikator der Landschaftsentwicklung in der Wetterau und am Untermain. - Jahresberichte der Wetterauischen Gesellschaft für die gesamte Naturkunde 153-157: 7-35.

Thomsen, K.J., Murray, A.S., Jain, M. \& BøtTer-Jensen, L. (2008): Labo- ratory fading rates of various luminescence signals from feldspar-rich sediment extracts. - Radiation Measurements 43: 1474-1486.

VISOCEKAS, R. (1985): Tunnelling radiative recombination in labradorite: Its association with anomalous fading of thermoluminescence. - $\mathrm{Nu}$ clear Tracks and Radiation Measurements 10 (4-6): 521-529.

Wintle, A.G. (1973): Anomalous fading of thermoluminescence in mineral samples. - Nature 245: 143-144.

Wintle, A.G. \& Brunnacker, K. (1982): Ages of volcanic tuff in Rheinhessen obtained by thermoluminescence dating of loess. - Naturwissenschaften 69: 181-183.

Wintle, A.G. \& Murray, A.S. (2006): A review of quartz optically stimulated luminescence characteristics and their relevance in singlealiquot regeneration dating protocols. Radiation Measurements 41: 369-391.

ZÖLLER, L. (1989): Geomorphologische und geologische Interpretation von Thermolumineszenz-Daten.- Bayreuther Geowissenschaftliche Arbeiten 14:103-112.

Zöller, L. (1995): Würm- und Rißlößstratigraphie und Thermolumineszenz-Datierung in Süddeutschland und angrenzenden Gebieten. - Habil.schrift Fak. f. Geowiss. Univ. Heidelberg, (unpublished).

ZÖLLER, L. \& SEMMEL, A. (2001): 175 years of loess research in Germany long records and "uncon-formities". - Earth Science Reviews 54: 19-28 